concerned with the proper administration of city finances. Tours gives us a model "executive" budget, ample details supporting the salary requests and clear explanations of items presented as lump sums. The two sections of a correct budget, revenue as well as expense, are presented in equal detail. So much for the form. As to content, we see that, owing to careful financing, the city is able to provide six-sevenths of its funds without levying upon the citizen body, a fact which has tremendous significance to American cities, forced as they are to levy upon the citizen body for much more than half of the total sums needed.

Indeed, it might be said that in this simple relation of taxes to other sources of revenue is contained the entire theory of municipal government. Are we to keep our cities in leash, in an economic sense, or are we going to provide them with substantial independence so that they may be free to develop their resources and use their financial and social advantages with as full an initiative as the private corporation? We have given cities home rule but have we shown them sufficiently how to use this great lever to lift themselves out of the financial mire and acquire, like Tours, a substantially self-supporting basis? Can we now apply the energy we have shown in solving problems of internal efficiency to problems of external efficiency, so that the American city of the near future may take its place not only as a living, responsive, social organism but as a successful economic enterprise as well? It is along lines such as these that the consideration of a municipal instrument such as the budget of Tours may be found to have suggestive value.

\title{
HOW THE UNITED STATES CAN HELP BUILD HOMES
}

\author{
BY STEPHEN CHILD \\ Landscape Architect and Cortsulting Engineer, Formerly District Town Planner, United States \\ Housing Corporation
}

$A$ defense of the war housing work of the federal government and a proposal to capitalize the war experience. $\quad:$ : $\quad$ : $\quad$ : $\quad$ ::

\section{I}

From all over the country, in fact from all over the civilized world comes the cry for houses and more houses. And why not, when during the past five years so many have been destroyed and so few new ones built! In this country during this period the building of new houses suitable for workers has been practically at a standstill, has amounted to less than one per cent of the normal increase of such building, and to this new building the federal government itself through its several war agencies has been the principal contributor. How can this invaluable experience accumulated in Washington in the course of its war housing work, be placed at the disposal of a house-hungry Nation? It is believed by many that the answer is the enactment of the Tinkham Bill which provides that there shall be "created in the Department of Labor a Bureau of Housing and Living Conditions, which, 
for the purpose of increasing the productive capacity and well-being of workers and of promoting good citizenship, shall be charged with the duty of

(a) Investigating the housing and living conditions of the industrial population;

(b) Conducting research and experimentation looking toward the provision and publication of such information as will make economically practicable the elimination of slums, the improvement of living conditions, the reduction of the construction cost of dwellings, and the financing of extended home-building operations without federal appropriation;

(c) Assisting communities during the present housing shortage in making available to the utmost extent all existing housing facilities; and

(d) Serving as a clearing house of information on housing and living conditions."

Section 2 of the bill provides "That to this bureau shall be transferred the collections of plans, books, pamphlets, reports, and other material gathered by the United States Housing Corporation and by the Housing and Transportation Division of the Emergency Fleet Corporation which would be of use for the purposes of the Act."

\section{II}

The acute problem of war-time housing shortage was attacked by three organizations, the United States Housing Corporation, an executive agent of the Housing Bureau of the Department of Labor; the Emergency Fleet Housing Corporation, a similar agency of the United States Shipping Board, and the Ordnance Division of the War Department. Of these three the Housing Corporation has recently issued a monumental report ${ }^{1}$ literally a mine of information, and as this corporation was perhaps the most completely organized, a brief outline of its history and accomplishments may be in order.

In the early summer of 1917 it became evident that the production of munitions, ships, guns and supplies was being checked by bad housing conditions. "Shelves to sleep upon, or the three-shift beds which never cooled between use, food handled almost in troughs as for swine; the absence of bathing, resting, and recreation facilities; transportation to and from work in continuous discomfort-all these conditions made big pay a mere incident of discontent and migration from one job to another in the hope of finding some place fit to live in." The managers of the industries involved could not possibly solve the problem,-no private initiative could and the government was simply forced to take it in hand. The reports above mentioned give the results of a portion of the government's endeavor.

An entirely new organization had to be assembled, the initial steps being taken by the Committees and advisors of the Council of National Defense. Headed by Mr. Otto M. Eidlitz unpaid volunteers began collecting data and to outline procedure. After many months, in March, 1918, congress appropriated $\$ 50,000,000$ for houses for ship workers, and until the Shipping Board established its own organization Mr. Eidlitz and his collaborators aided them in an advisory capacity. But the study of the problem of housing for other war workers was continued,

${ }^{1}$ Report of the United States Housing Corporation. (U. S. Bureau of Industrial Housing and Transportation.) Vol. II. Washington, Government Printing Office, 1919, 524-xix pages. Illus. plans. $11 \frac{3}{6} \times 9$ inches. Price $\$ 1.50$. 
a tentative scheme of procedure was prepared and some of the most pressing housing shortage situations investigated,--expenses being paid from the President's emergency fund and the Navy Department. Finally, June 18, 1918, real authority was given to expend $\$ 60,000,000$ (appropriated June 4, raised to $\$ 100,000,000$ July 8) "for the purpose of providing housing, local transportation, and other general community utilities for such industrial workers as are engaged in arsenals and navy yards of the United States and industries connected with and essential to the national defense, and their families * * * only during the continuation of the existing war." But not until July 25, 1918, was the United States Housing Corporation, created as an executive agent of the Housing Bureau, and authorized to expend these funds for actual acquirement of land and for construction. Between this date (July 25th) and the armistice, in 109 days, this Corporation produced completely worked out plans and specifications for 83 projects, its work extending as far afield as Puget Sound and New Orleans,-Bath, Maine, and Mare Island, California. For 60 of these projects, involving an estimated expenditure by this Corporation of $\$ 63,481,146.65$, construction contracts had already been let on November 11th, a very remarkable record. The story of how it was done is an interesting one.

Applications for aid poured in, a steady stream of them, and all were listed and taken up in the order of their apparent importance. First a preliminary investigation on the ground was made, the investigator canvassing the situation as completely as possible, consulting with manufacturers, laborers, civic organizations and so on.

In the meantime the Washington office of the Corporation was being organized, various divisions were established, including architecture, engineering, town planning, legal, real estate, transportation, homes registration and later operating, and other divisions; each with recognized experts at the head and a suitable staff of assistants.

The preliminary investigator's report was given full and searching discussion by the chief and division heads. If the need was proved an allotment of funds was made, not always for new houses, however. Sometimes war contracts were placed elsewhere, again private enterprises were encouraged, all present housing was to be improved and made available and transportation facilities increased. If these combined did not solve the problem new house construction was authorized, never, however, in sufficient quantity to completely serve the need of any one community, but enough to help hold the most needed workers and never more than would be useful and valuable after the war.

A "real estate scout" was sent out and the vacant land question thoroughly sifted. Following his report again made to an inter-departmental committee of the corporation at Washington, "a second investigating team" was sent, usually composed of one man each from the architectural, engineering, town planning and real estate divisions, with a man from the transportation division when needful. The homes registration division in the meantime was busily at work listing all room vacancies in the community.

When this "second investigating team", arrived in the town each took up his special line thoroughly, the team meeting evenings to co-ordinate results, one member being appointed captain and all joining in formulating the report, covering the number and 
kind of houses to be built, the site or sites best suited and many other details. This second investigating team report was of utmost importance and while it was reviewed by the Chief and department heads of the Housing Corporation, and if found advisable modified, it usually became the basis of future action.

The site and size of the job thus determined, the next move was the appointment by the Washington office of a committee of designers, usually three, an architect, an engineer and a town planner, these three being held responsible jointly for the project. The Washington office helped them with standardized data and requirements, and with these, followed by study on the ground a preliminary plan with estimates was submitted, again to the chief and department heads of the Housing Corporation. Many were the alterations and adjustments made at this stage, to make sure there were no inconsistencies, overlaps, or omissions.

Then came final plans and specifications and following further conferences at Washington over these, contracts were let, under a practically graftproof form of contract which had been carefully worked out. A requirement division was organized, estimating standards determined and all materials at a fixed price purchased through the construction division of the army. In the meantime of course the real estate division had negotiated the acquisition of the site or sites decided upon.

A project manager was now appointed for each job to co-ordinate the work of the corporation, designers, contractors and sub-contractors, eliminating as far as possible all friction and delay.

Contracts let, material ordered and work started, the committee of designers selected a works superin- tendent, who after approval by the Washington office, was given supreme charge of construction on the job.

All this organization had to be rapidly assembled and much of it was worked out as the program developed, but in spite of occasional misunderstandings, and duplication of fields of work, on the whole one of the most striking accomplishments of the corporation was that through a necessarily complicated co-operation of many hundreds of people who, for the most part, had never worked together before, with almost no delay due to personal friction, it produced in 109 days, the remarkable results already noted.

\section{III}

In serving its war purposes the Housing Corporation and the United States Shipping Board have together produced and in a measure compiled, as by-products, by far the largest and best organized collection of information in existence on contemporary American industrial housing, town planning and related matters. The recent Housing Corporation report sets forth all too briefly only what this organization has done-no similar record has been published by the Shipping Board. The proposed housing bureau or service (a better term) should no doubt first make a careful analysis of all this compiled data and publish its conclusions; something there was no opportunity to do in the rush of closing up affairs.

Let us suppose such a housing service authorized and effectively organized. This is perhaps neither the time nor the place to outline in detail its organization, but it would no doubt include a Director and various appropriate division heads. Their first duty would be the above mentioned careful analysis of accumulated data. 
Without doubt such a service would immediately be flooded with requests for aid and advice. One cannot take up a paper without reading of the more or less intelligent efforts that are being made all over the country to relieve serious housing troubles. The chambers of commerce, boards of trade, or real estate boards of most of our large cities, as well as individual manufacturers, large and small are struggling in a tangled morass of difficulties and all would welcome the expert advice this service would be so well able to give.

Let us set our proposed service to work in aid of a manufacturing city suffering as what one is not from housing trouble. No doubt such a community if it is at all progressive, has already done some investigation work, but there is an honest difference of opinion as to what to do next. A communication is sent to the housing service stating the facts as they exist, and the need for advice established a preliminary investigator, a man trained by war-time experience is sent to our city. After canvassing the situation, consulting with officials, manufacturers, laborers and various organizations, he reports his findings to the Washington office. The director and heads of divisions there, men of broad vision and thorough training will be able, after full and searching discussion, to advise our community in many ways. They may show, for example, how present housing conditions can be improved and made available, or recommend changes in transportation facilities. Homesregistration-bureaus established by the United States Housing Corporation and the advice of their transportation experts relieved a very large amount of the acuteness of war-time housing difficulties, - tided many a community over very trying situations until actual construction could really solve the problem. But no doubt this is not sufficient for the case in hand. Houses must be built, but of what type and where and whence the funds?

While the service at Washington can furnish no financial aid, a very wise provision, it can advise, no doubt, through the means of a second investigation committee, about methods of financing such undertakings, and about the selection and purchase of sites, particularly about types and styles of houses, furnishing reliable estimates of their cost, for while the government costs were inflated by war conditions, these can readily be scaled down to those of the present day.

The Federal war-housing agencies made a careful study of the recent growth of municipal utilities, prepared engineering standards in great detail, studied best methods of surface improvements, of drainage and grading, as well as the fundamental principles of street, alley, sidewalk, and lot planning. The second investigating committee with this data in hand and analyzed, can advise about all these, and particularly help our city co-ordinate its plans, advising its local committee of designers, undoubtedly needed if the problem is of any size.

When it comes to the question of type of dwellings and other buildings, it will be found that, our service has standard plans of bungalows, detached houses, semi-detached houses, two-flat houses, semi-detached two-flat houses, dormitories, cafeterias, schools and many "standard details," all ready and these are increased in value by the actual results of their use by the government.

Another matter to which the government gave careful study was "general appearance," considering its financial value, elements producing it, consistency in design, variety, and the 
taking advantage of the natural features, together with the importance of the general effect of building. All these points can be advised upon in the light of actual experience in many sorts of problems. When there is any existing natural beauty, either on the land purchased or visible from it, it can be shown how to preserve it and display it to the best advantage. Fortunately, the roughest land, and that with brooks and large trees, is likely to be both the most interesting to look at and walk through, and the most expensive to build on, and so on both counts best fitted for public reservations, the most attractive of these areas can later be developed as parks and public spaces of various kinds, where these are needed.

The real estate division of the Housing Corporation accumulated some very valuable experience in regard to methods of purchase of land, and when our city is ready for actual work the corporation's experience with regard to forms of contract and of purchasing material will be valuable preventing serious and expensive mistakes. So all along the line, from start to finish, can this service help our city's housing needs.

\section{IV}

To be sure, the Housing Corporation was investigated, quite largely for political purposes. Among the other unfair conditions of this investigation, it is to be noted that the corporation was not allowed the privilege of cross-examination by its attorney and one morning only out of four months of questioning, was granted for the submission of rebuttal evidence, the conclusions of the report making no mention of this evidence.

The Senate committee's main criticism is that the United States Housing
Corporation adopted in general a permanent type of housing, their alleged unnecessary excellence coming in for much sarcasm.

The question raised is a fundamental one; of special interest today on account of the housing shortage. England went into the construction of war housing to an extent many times greater than did this country, building houses on an even more permanent type than ours. Several private housing corporations, notably The Bridgeport Housing Company of Bridgeport, Connecticut, just prior to the time when this country entered the war built for the industrial workers of their crowded city a number of houses and apartments similar to those later on erected in Bridgeport by the United States Housing Corporation.

The question was carefully considered, by the government experts, whose judgment may well be considered to be better than that of the Senate committee and its clever attorney. The war loss to the government in dollars and cents will probably be about the same in the case of the permanent and temporary housing. But, in the case of the permanent structures there is something very definite and useful left to show for the money spent. The salvage value of the temporary houses is very slight, whereas they require almost as great an outlay for "utilities," sewer, water supply, drainage, paving, lighting, etc. In other words, the government has secured, without extra expense, the incidental salvage of having created a decent American home. Of all assets which the country has today, none is greater, none is needed more than good housing and the individual ownership of homes which create loyal and useful citizenship. There was nothing to warrant the United States Housing Corporation to a procedure of filling up some 
of the best towns in the United States with a lot of cheap hovels which would have degenerated into slums and which would have been a disgrace to many cities now provided with decent government housing. The type of the house built was the type demanded and ready to be paid for by the skilled worker. $\mathrm{He}$ is doing it. All of the first-class houses built by the Housing Corporation were filled up as fast as they were constructed. The last houses in demand by the tenants or by the prospective home owners, have been the cheap temporary houses recommended in the Senate committee's report. "Furthermore this government housing will long out-last any of the other physical things constructed for the war. In 15 or 20 years the battleships will be scrapped, the guns and forts will be out-ofdate and nothing will be left except these towns, and in 20 years they will only have begun their usefulness both for their own inhabitants and as examples for the country."

The United States Housing Corporation has completed construction of houses and apartments for 6,000 families and quarters for some 8,000 single workers. Out of a possible occupancy returning at the rate of some $\$ 2,200,000$ per annum it has rented houses under an annual rental of $\$ 1,985,000$. It has sold to good advantage a large amount of movable property and has adjusted all cancelled and curtailed contracts.
By June 30, 1920, the United States Housing Corporation will have completed the bulk of its task of converting its properties into securities. There is every expectation that the total return to the United States Treasury will be:

$\$ 32,500,000$ cash returned soon after the Armistice.

10,000,000 interest bearing securities of Transportation Companies.

$30,000,000$ eash and interest bearing mortgages on real property.

$\$ 72,500,000$

The remaining $\$ 27,500,000$ must stand as a war investment. $A$ considerable portion of this was spent in making available suitable existing quarters and homes to thousands of essential workers through homes registration bureaus, which the Housing Corporation established throughout the country. Also, improved transportation facilities for many communities and the weeding out of non-essential demands for housing, for construction of temporary buildings and for excess war cost all along the lines.

It is a fair question "What other war agency of like size has made so good a showing?"

With the reassembling of congress, after the heat of the campaign, it is reasonable to hope that attention may be concentrated upon this housing question and some such bureau or service, as is here outlined, established. It could do a great deal of good. 